\title{
ANALISIS SISTEM INFORMASI AKUNTANSI DAN SISTEM PENGENDALIAN INTERN PERSEDIAAN BARANG DI TOKO BAPAK WALUYO DI KEC. GONDANG TULUNGAGUNG
}

\author{
Dhanang Tias Anggoro, Rulin Yunestri, Shafirah Nurlita Chaniago \\ [Program Studi Akuntansi, Fakultas Ekonomi, Universitas Tulungagung]
}

\begin{abstract}
The accounting information system and internal control system are components that collect, classify, process, analyze, and combine relevant financial information for decision making by external parties (such as the Government, the public, investors, and creditors), especially the management. Mr. waluyo's shop is a shop that sells building materials and electrical equipment so that it has quite a lot of stock. This study aims to analyze inventory accounting information systems and internal control systems that apply to Mr. Waluyo's Store. This research uses descriptive research method. The results showed that the accounting information system at Mr. Waluyo's shop still uses a manual system, namely the internal control system, but is very helpful and supports the accounting information system at Mr. Waluyo's shop so as to minimize errors in the inventory system.
\end{abstract}

Keywords: Accounting Information Systems, Internal Control Systems Supplies.

\begin{abstract}
Abstrak
Sistem informasi akuntansi dan sistem pengendalian internal merupakan komponen yang dikelompokkan, mengklasifikasikan, pengolahan, menganalisis, serta menggabungkan informasi keuangan yang sesuai untuk pengambilan keputusan dari pihak eksternal (misalnya Pemerintah, masyarakat, investor, dan kreditur) terutama pihak manajemen. Toko Bapak waluyo merupakan toko yang menjual bahan bangunan dan alat listrik sehingga memiliki stok barang yang cukup banyak. Penelitian memiliki tujuan guna melakukan analisis sebuah informasi akuntansi persediaan dan sistem pengendalian secara internal, yang berlaku di Toko Bapak Waluyo. Penelitian ini menggunakan metode penelitian deskriptif. Dari hasil penelitian ini menghasilkan sistem inofrmasi akuntansi di Toko Bapak Waluyo tetap memakai sistem sederhanaa yaitu sistem pengendalian internal namun begitu membantu dan menunjang sistem informasi akuntansi di Toko Bapak waluyo sehingga meminimalkan terjadinya kesalahan pada sistem persediaan barang.
\end{abstract}

Kata Kunci: Sistem Informasi Akuntansi, Sistem Pengendalian Internal Persediaan Barang. 


\section{PENDAHULUAN}

Berkembangnya zaman menyebabkan teknologi informasi berhasil mengubah dunia usaha dengan keadaan penuh dengan saingan yang begitu banyak, sehingga menunut perusahaan untuk terus memajukan usahanya supaya lebih feisien guna pencapaian tujuan perusahaan. Dalam perusahaan dagang, pengelolaan akan persediaan begitu diprioritaskan, sebab berbeda dengan perusahaan jasa yang enggan memiliki persediaan sehingga tidak membutuhkan pengecekan terhadap persediaan. Terdapatnya sistem informasi yang bagus dapat menghasilkan informasi yang akurat sesuai kebutuhan. Informasi yang bagus ialah informasi yang mampu diutarakan pada waktu yang tepat, bermanfaat, serta dapat di andalkan. Salah satu yang penting di sebuah perusahaan adalah sistem informasi akuntansi.

Sistem Informasi Akuntasi merupakan suatu elemen yang dikumpulkan, digolongkan, diolah, dianalisa, dan dikombinasikan dengan informasi keuangan yang akurat guna mengambil keputusan dari pihak eksternal, (misalnya pemerintah, rakyat, investor, dan kreditur), dan pihak internal terutama manajemen. Selain itu, dengan adanya sistem informasi berguna untuk menyajikan pengendalian yang memuaskan guna menjaga asset perusahaan. Pengawasan ialah fungsi dari manajemen dengan tujuan guna mengusahakan untuk aktivitas dapat berjalan seimbang dengan perencanaan yang memusat pada sasaran yang konvensional.

Toko Bapak Waluyo merupakan perusahan dagang yang menjual bahan-bahan bangunan serta alat listrik dimana Toko Bapak Waluyo bertindak sebagai pedagang satuan. Pada berbagai merek barang dagang mewujudkan kerentanan kesalahan terhadap pencatatan perediaan, sehingga diperlukan pengecekan serta adanya sistem yang jelas guna memastikan persediaan barang dagangan Toko Bapak Waluyo tidak mengalami kerugian barang.

Guna menyelesaikan masalah ini dibutuhkan suatu manajemen dagangan yang baik. Manajemen yang baik diperlukan untuk Menyusun sistem inoformasi yang berperan dalam menangani perusahaan dalam keamaan persediaan. Sehingga, dalam penelitian ini memiliki tujuan guna melakukan analisis apakah sistem informasi akuntansi persediaan, serta sistem pengendalian internal di Toko Bapak Waluyo telah diterapkan dengan baik dan tersusun. 


\section{KAJIAN TEORI}

\section{Pengertian Sistem Informasi Akuntansi}

Suatu elemen yang dikumpulkan, dikelompokkan, diolah, dianalisa, dan dikombinasikan menurut informasi keuangan yang akurat guna mengambil keputusan dari pihak eksternal (misalnya pemerintah, masyarakat, investor, kreditor) dan pihak internal, Baridwan (2013:4).

\section{Tujuan dan Manfaat Sistem Informasi Akuntansi}

Menurut Diana dan Setiawati (2011: 5) terdapat 7 manfaat serta tujuan dari Sistem Informasi Akuntansi ialah sebagai berikut.

1. Menyelamatkan harta atau asset perusahaan. Harta kekayaan perusahaan meliputi; kas perusahaan, persediaan barang dagang, dan asset tetap perusahaan.

2. Mewujudkan berbagai informasi guna mengambil putusan.

3. mewujudkan informasi guna pihak eksternal.

4. mewujudkan informasi untuk penilaian kinerja karyawan disetiap divisi.

5. mencadangkan data terdahulu untuk kepentingan audit (pemeriksaan).

6. mewujudkan informasi untuk penyusunan dan evaluasi anggaran perusahaan.

7. mewujudkan informasi yang dibutuhkan dalam kegiatan perencanaan dan pengendalian. Sesuai dengan definisi sistem informasi akuntansi, maka dapat disimpulkan tujuan serta manfaat sistem informasi akuntansi adalah sebagai pengolahan transaksi (transaction processing) dan pengolahan informasi (information processing).

1. Prosedur Transaksi

Transaksi pada perusahaan mengharuskan melakukan sebuah pengoperasian, menyelenggarakan arsip serta melakukan pencatatan up to date, dan mencerminkan sifat organisasi. Transaksi akuntansi ialah transaksi transfigurasi yang memiliki nilai ekonomis. Tipe dasar transaksi yaitu : (1) penjualan jasa atau produk, (2) pembelian bahan baku, barang dagang, jasa serta asset tetap dari supplier, (3) penerimaan kas, (4) pengeluaran kas kepada supplier, dan (5) pengeluaran kas gaji untuk karyawan. Sebagai pengolah transaksi, sistem informasi akuntansi berperan mengatur serta mengoperasionalkan semua aktivitas transaksi perusahaan.

2. Pengolahan Transaksi

Sistem informasi akuntansi ialah untuk menyajikan informasi yang dibutuhkan dalam pengambilan keputusan yang dilakukan untuk aktivitas yang disebut pemrosesan transaksi. Sebagian keluaran yang dibutuhkan oleh pemrosesan transaksi telah disediakan oleh sistem. Akan tetapi, Sebagian besar didapatkan dari sumber lain, baik dari internal ataupun eksternal perusahaan. Pemakai utama pemrosesan transaksi ialah manajer perusahaan. Mereka memiliki tanggung jawab pokok guna pengambilan putusan yang berkenaan dengan perencanaan serta 
pengendalian operasional perusahaan. Pengguna output lainnya ialah karyawan penting, misalnya akuntan, insinyur dan pihak eksternal misalnya investor dan kreditor.

\section{Pengertian Sistem Pengendalian Internal}

Sistem pengendalian internal ialah suatu sistem yang dibuat guna memberikan jaminan keamanan bagi komponen yang ada di dalam perusahaan (Sujarweni, 2020). Tujuan perusahaan dalam pembuatan sistem pengendalian internal ialah :

1. Guna menjaga asset organisasi.

2. Guna menjaga relevan laporan keuangan perusahaan.

3. Guna menjaga kemahiran operasi perusahaan.

4. Guna menjaga kedisiplinan dijalankan dalam kebijakan manajemen.

5. Supaya semua lapisan yang ada di perusahaan tunduk terhadap hukum dan aturan yang telah ditetapkan di perusahaan.

Pentingnya pengendalian internal adalah penggunaan metode oleh direksi, manajemen, serta pimpinan yang menciptakan rasa optimis untuk mencapai tujuan berikut: (1) Keefektivan serta operasi yang tepat guna; (2) Ketepatan pada pelaporan keuangan tahunan; (3) Kepatuhan akan hokum serta aturan. (Prabowo et al., 2021)

\section{Ancaman Terhadap Sistem}

Adanya ancaman perusahaan karena sebuah sistem yang dijalankan oleh perusahaan. Ancaman tersebut dapat dicegah dan diminimalisirkan karena adanya suatu pengendalian internal :

1. Risiko akibat perbuatan disengaja.

Merusak sebuah sistem secara secanga, misalnya menghilangkan dokumen, merusak sistem, menginput data yang tidak benar, serta mencuri data guna sabtotase pesaing perusahaan.

2. Risiko akibat perbuatan tidak disengaja.

Perbuatan yang dapat meruskan sistem secara tidak sengaja, misalnya tidak sengaja menghilangkan dokumen, tidak sengaja menginput data yang tidak benar, rusak akibat bencana alam serta terjangkitnya virus di dalam data dalam komputer.

\section{Komponen Pengendalian Internal}

Pengendalian internal dalam perusahaan begitu penting guna pengawasan asset perusaahan. Tujuan dari sistem pengendalian internal supaya tercapai dengan baik, maka layak mempertimbangkan komponen dari sistem pengendalian internal tersebut. Elemen pengendalian internal COC terdriri dari beberapa hal berikut :

1. Lingkungan Pengendalian 
Lingkungan Pengendalian terdiri dari aktivitas, kearifan dan prosedur yang menggambarkan seluruh sikap manajemen, direksi serta pemilik dari suatu entitas atas pengendalian internal serta pentingnya sebuah pengendalian internal terhadap suatu entitas. Untuk dapat memahami serta meniai lingkungan pengendalian, seorang audit harus mempertimbangakn sub-elemen pengendalian internal. Adapun sub-elemen yang sangat penting dalam pengendalian internal sebagai berikut :

a) Integritas serta nilai etika

b) Komitmen Terhadap Kompotensi

c) Partisipasi Dewan Direksi dan Komisaris atau Komite Audit

d) Filosofi Manajemen dan Gaya Operasi

e) Struktur Organisasi

f) Kebijakan dan Praktik Sumber Daya Manusia

2. Penilaian Risiko

Penilaian resiko guna laporan keuangan ialah pengidentifikaisan serta analisis manajemen terhadap risiko yang akurat terhadap penyusunan laporan keuangan yang sesuai dengan PABU. Proses penilaian risiko yaitu pengidentifikasian factor yang memengaruhi risiko, menilai berharganya risiko serta kemungkinan terjadinya, dan penentuan Tindakan yang harus dilakukan guna meminimalisir risiko.

3. Aktivitas Pengendalian

Aktivitas pengendalian ialah kebijakan serta prosedur, kecuali yang telah dimaksudkan dalam keempat elemen lainnya, yang membantu guna memastikan bahwa Tindakan yang signifikan telah dilakukan guna meminimalisir risiko dalam pencapaian tujuan organisasi. Terdapat kemungkinan banyak aktivitas pengendalian di setiap entitas, termasuk pengendalian secara sederhana serta pengendalian secara implusif. Aktivitas pengendalian tersebut masuk ke dalam lima jenis aktivitas di bawah ini :

a) Pembagian tugas yang sesuai.

b) Yurisdiksi yang tepat terhadap transaksi serta aktivitas.

c) Dokumentasi serta catatan yang memuaskan.

d) Pengendalian fisik atas aset serta catatan.

e) Pengecekan terhadap pekerjaan secara independen.

4. Informasi dan Komunikasi

Sistem informasi dan komunikasi akuntansi memiliki tujuan ialah memulai, mencatat, memproses, serta melaporkan transaksi yang terjadi dalam suatu entitas sera guna menjaga akuntabilitas harta yang terkait. Sistem informasi dan kmunikasi akuntansi terdapat beberapa sub-elemen yang membentuk menjadi kelompok transaksi, misalnya penjualan, retur penjualan, penerimaan kas, pembelian dan lain-lain. Dari setiap 
transaksi, sistem akunansi harus memenuhi enam tujuan audit yang terkait transaksi misalnya keterjadian, kelengkapan, keakuratan, pemindahbukuan serta pengikhtisaran, klasifikasi dan waktu.

5. Pengawasan

Pengawasan yang berkaitan dengan niali yang berjalan atau nilai berkala terhadap kualitas pengendalian internal oleh manajemen guna menentukan bahwa pengendalian dijalakan sesuai tujuannya serta dimodifikasi apabila diperlukan adanya perubahan keadaan. Informasi yang dinilai berasal dari berbagai sumber, termasuk studi terhadap pengendalian internal yang telah ada, laporan internal auditor, laporan pengecualian terhadap aktivitas pengendalian, laporan dari regulator, seperti dari regulator perbankan, timbal balik dari personil operasi, dan keluhan dari pelanggan mengenai biaya tagihan. Untuk beberapa perusahaan besar departemen audit internal ialah fungsi penting guna melakukan pengawasan efektif.

Untuk menjadi efektif, pengendalian internal harus menjalankan fungsi olah staf yang independent dari departemen operasional maupun dari departemen akuntansi serta melaporkan langsung kepada yurisdiksi yang lebih tinggi di organisasi, apakah di manajemen puncak atau kepada komite audit dari dewan direksi.

\section{Persediaan}

Persediaan barang dagang ialah barang yang dipunyai oleh perusahaan guna diperjualkan ulang. Persediaan pada umumnya meliputi jenis barang yang banyak serta bagian yang cukup berarti dari seluruh aktiva perusahaan. Selain itum transaksi yang berhubungan dengan perusahaan ialan aktivitas yang sering terjadi, Soemarso (2009).

\section{Metode pencatatan persediaan}

Pemegang peran yang pentig guna menentukan hasil dari usaha atau pendapatan, (harga pokok barang yang terjual). Perlu diketahui terlebih dahulu, jumlah permbelian bersih persediaan awal periode akuntansi. Menurut Zaki Baridwan (2013) terdapat 2 macam metode pencatatan persediaan yaitu :

a. Metode Persediaan Buku (perpetual)

Metode buku pada setiap jenis persediaan dibuatkan rekening tersendiri yang termasuk buku pembantu persediaan. Buku pembantu terinci dan di awasi melalui rekening control persediaan barang melalui buku besar. Rekening yang digunakan untuk mencatat persediaan ini terdiri dari beberapa kolom yang dapat digunakan guna pencatatan pembelian, penjualan dan saldo persediaan. Setiap terdapat perubahan dalam persediaan akan diikuti oleh pencatatan dalam rekening persediaan sehingga jumlah persediaan dapat diketahui dengan melihat saldo rekening persediaan sewaktu-waktu. 
b. Sistem Periodik (fisik)

Persediaan periodic dilakukakan dengan memakai perhitungan secara fisik. Transaksi persediaan barang dagangan menggunakan metode pencatatan ini tidak langsung berkaitan dengan barang dagangan. Misalnya terjadi pembelian barang dagang akan dicatat di rekening pembelian dan penjualan akan dicatat di rekening penjualan. Ketika terjadi pembelian atau penjualan transaksi tidak dicatat pada rekening persediaan. Metode yang digunakan dalam sistem periodik antara lain:

1. Metode Tanda Pengenalan Khusus

Perusahaan yang spesifik menggunakan metode ini karena penjualan barang yang sedikit dengan harga yang mahal. Setiap adanya pemasukan barang diberi tanda pengenal khusus untuk menunjukkan harga satuan yang sesuai faktur yang diterima ketika pembelian.

2. Metode Rata-Rata

Metode rata-rata ini cara perhitungannya dengan menghitung rata-rata dari seluruh harga pembelian, jumlah barang yang dibeli selama satu periode.

3. Metode First In First Out (FIFO)

Sistem dalam metode FIFO ini ialah barang yang keluar terlebih dahulu menunjukkan bahwa barang tersebut barang yang lebih dulu masuk.

4. Metode Last In First Out (LIFO)

Sistem dalam metode LIFO ini ialah barang yang keluar terlebih dahulu menunjukkan barang yang terakhir masuk.

5. Metode Persediaan Dasar

Metode persediaan dasar ialah metode yang harus menetapkan jumlah minimum perusahaan pada setiap saat, baik dari segi kuantitas maupun satuan atau yang kerap disebut sebagai basic stock . 


\section{METODE PENELITIAN}

\section{Jenis Penelitian}

Metode penelitian yang digunakan adalah deskriptif dan kualitatif. Penelitian ini dilaksanakan dalam keadaan yang alamiah secara langsung terhadap sumber data, pengumpulan data dengan menggunakan instrument penelitian serta data yang sudah terkumpul berupa data diri perusahaan, visi dan misi perusahaan, struktur perusahaan, job description, dan proses pencatatan persediaan Di Toko Bapak Waluyo.

\section{Tempat dan Waktu Penelitian}

Penelitian bertempat di Toko Bapak Waluyo kecamatan Gondang Tulungagung. Rentang penelitian ditetapkan selama 1 hari, pada tanggal 21 Desember 2021.

\section{Metode Pengumpulan Data}

Pengumpulan data menggunakan metode yang di antaranya adalah :

1. Observasi, iala sebuah Teknik yang dilakukan guna mengetahui kondisi serta permasalahan yang dihadai perusahaan.

2. Wawancara, ialah Teknik pengumpulan data dengan melakukan pengajuan pertanyaan mengenai segala sesuatu terhadap pemimpin dan karyawan perusahaan yang bersangkutan. Teknik ini dilakukan guna memperoleh data secara langsung atas sistem persediaan barang di perusahaan.

3. Dokumentasi, ialah usaha yang dilakukan guna pengumpulan data yang berhubungan dengan penelitian, cara memakai dokumentasi yang tersedia dari berbagai sumber informasi guna pencapaian tujuan sesuai harapan. metode ini digunakan guna memperoleh data yang diperlukan secara langsung dari Teknik wawancara tentang sistem persediaan barang di Toko Bapak Waluyo.

\section{Metode Analisis}

Metode analisi yang digunakan dalam penelitian ini ialah analisis deskriptif. Analisis deskriptif adalah metode pembahasan dengan menguraikan, menggambarkan, membandingkan, serta menerangkan suatu data sehingga mampu ditarik kesimpulan guna menjawab permasalahan dalam penelitian yang sedang dilakukan. 


\section{HASIL PENELITIAN DAN PEMBAHASAN}

\section{Sistem Informasi Akuntansi Persediaan Barang Toko Bapak Waluyo.}

Sistem informasi akuntansi persediaan ditujukan guna mengamankan persediaan yang barangkali terjadi, misalnya penyelewangan serta kecurangan yang dilakukan oleh suatu divisi. Menurut hasil penelitian di Toko Bapak Waluyo Sistem Informasi Akuntansi Persediaan Toko Bapak Waluyo meliputi sistem secara sederhana. Aktivitas sistem informasi akuntansi persediaan barang Toko Bapak Waluyo diilustrasikan pada alur bagan flowchart dibawah ini:

\section{a. Alur Pembelian Barang}

$A D M I N$

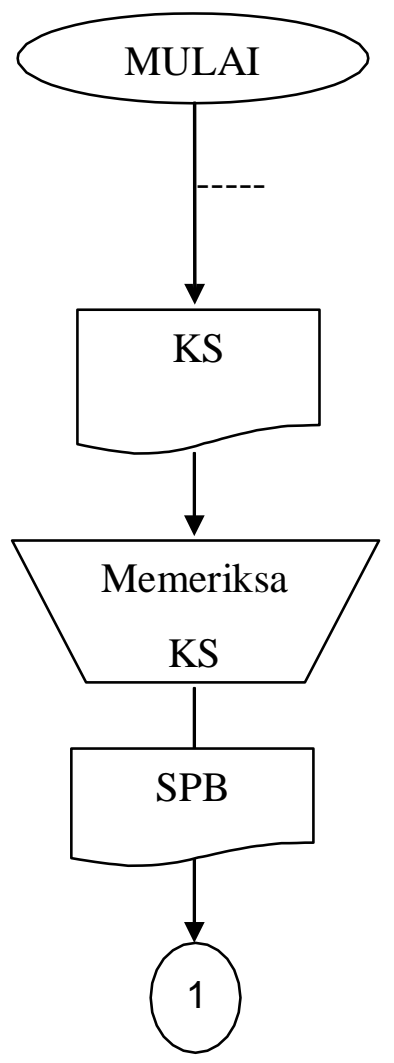

PEMILIK

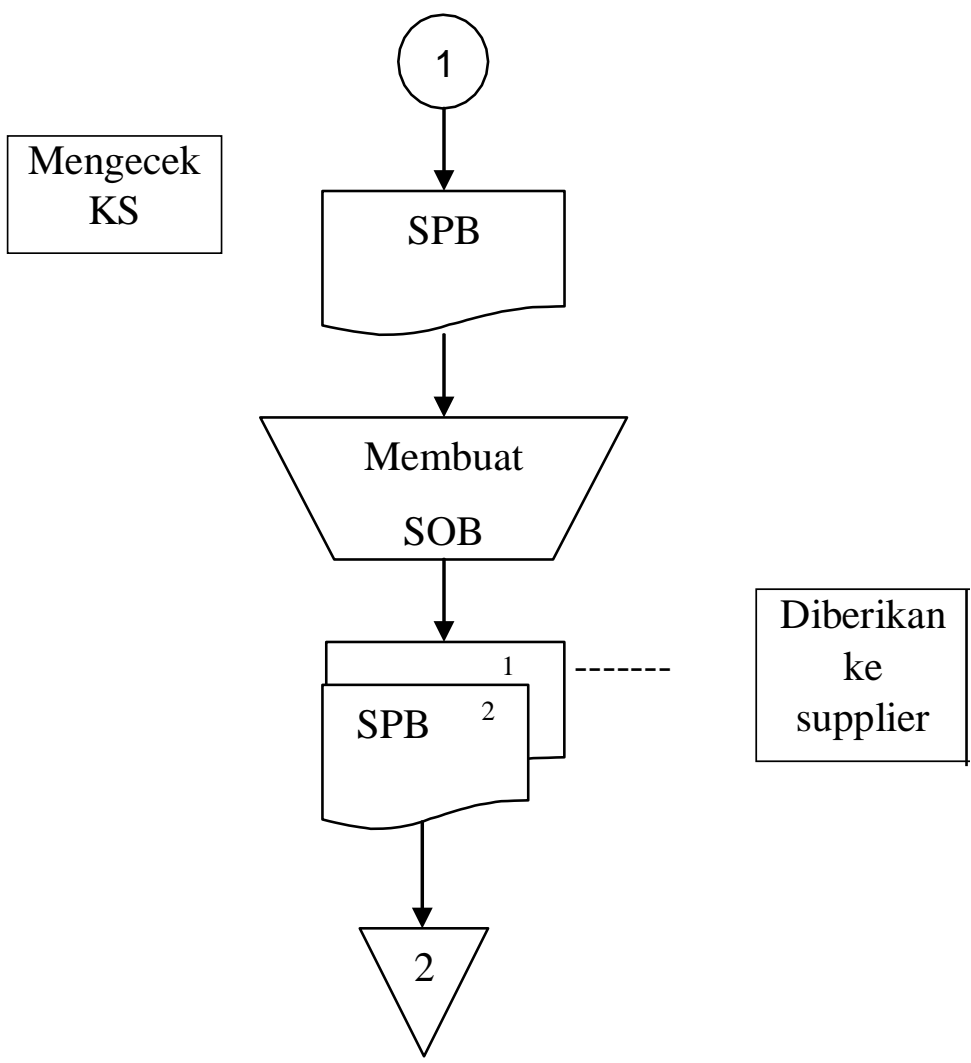

Gambar 1. Flowchart Alur Pembelian

Sumber : Olahan Sendiri berdasarkan penelitian (2021)

Berdasarkan Gambar 1. maka uraian atas sistem pembelian barang adalah :

Administrasi:

1. Pengecekan kartu stok dilakukan bidang administrasi

2. Pemeriksaan barang yang harus di order oleh bidang administrasi

3. Bidang administrasi membuat surat permintaan barang

Pemilik: 
1. Admin memberikan surat kepada pemilik

2. Pembuatan surat order barang kepada supplier sebanyak 2 rangkap

3. Surat order barang untuk supplier sebanyak 1 rangkap dan untuk administrasi sebanyak 1 rangak sebagai arsip.

\section{b. Alur Penerimaan Barang}

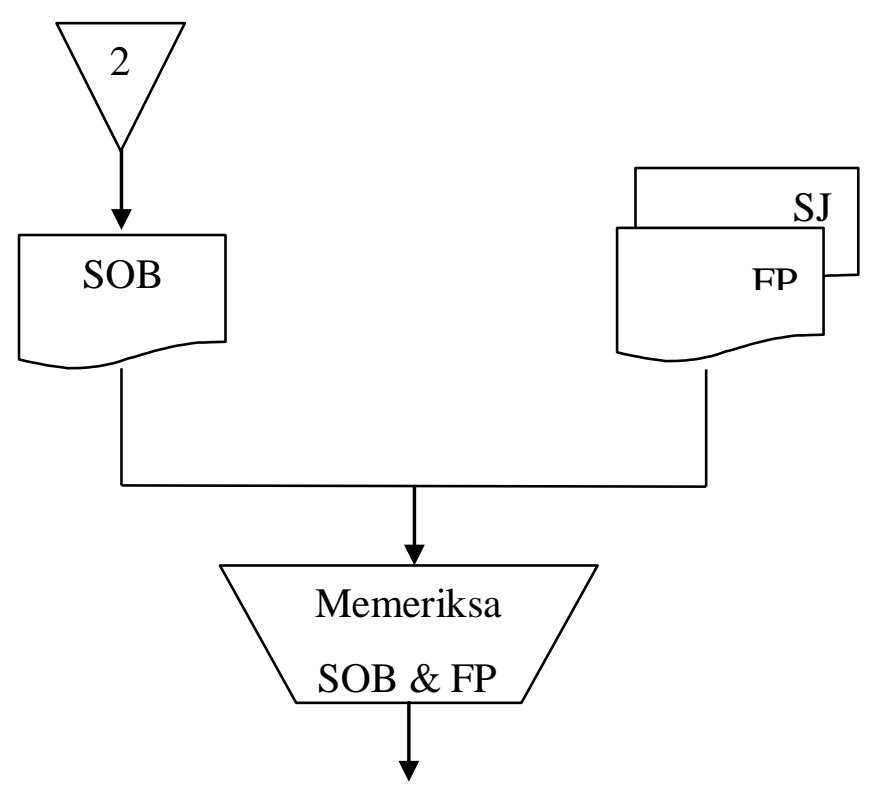

Keterangan :

KS $\quad$ : Kartu Stock

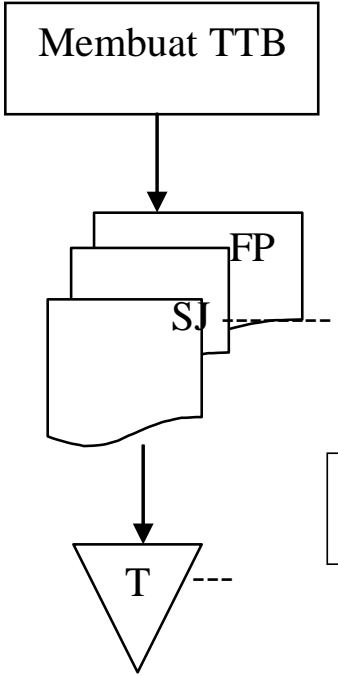

Diberikan

ke supplier

SPB : Surat Permintaan

Barang

SOB : Surat Order

Pembelian

FP : Faktur Pembelian

SJ : Surat Jalan

ARSIP

TTB : Tanda Terima Barang

Gambar 2. Flowchart Alur Penerimaan

Sumber : Olahan Sendiri berdasarkan penelitian (2021) 
Berdasarkan Gambar 2. maka uraian atas sistem penerimaan barang adalah :

Admin:

1. Bagian admin melakukan pengarsipan surat order barang serta faktur penjualan dari supplier guna di cocokkan kembali

2. Bagian admin melakukan pemeriksaan atas faktur penjualan dari supplier sesuai fisik barang yang diterima

3. Pembuatan tanda penerimaan barang oleh bagian admin

4. Semua dokumen diarsipkan oleh bagian admin

Bagian administrasi melakukan pertanggung jawaban dalam ketersediaan barang dagang. Sebelum dilakukannya order barang, bagian administrasi melakuakn pengecekan kartu stock (KS), yang kemudian melakukan pemeriksaan kartu stock barang yang harus dilakukan order. Tahap selanjutnya, pembuatan surat permintaan barang kepada supplier (SPB) yang dilakukan oleh administrasi. Surat permintaan barang diserahkan ke pemlik yang dituju guna ditinjau serta disetujui, setelah pemilik menyetujui Langkah selanjutnya pemilik mengeluarkan surat order barang sebanyak 2 rangkap, yang dimana rangkap 1 untuk supplier dan rangkap 2 untuk bagian administrasi.

Dalam penerimaan barang, bagian administrasi yang melakukan pertanggung jawaban guna menerima barang dari supplier yang relevan sesuai Arsip Surat Order Barang yang akan dicocokkan dengan faktur pembelian (FP) serta surat jalan (SJ) dari supplier. Tanda terima barang (TTB) dibuat oleh bagian administrasi, apabila keadaan barang sudah sesuai dengan Surat order barang, faktur pembelian dan juga surat jalan yang ada.

\section{Analisis Sistem Pengendalian Internal Toko Bapak Waluyo}

Sistem pengendalian internal merupakan suatu management responsibility, Sanyoto (2007 : 256). Sistem pengendalian internal yang paling berkepentingan ialah entitas organisasi/perusahaan adalah manajemen (lebih tegasnua lagi ialah top management/direksi), sebab dengan adanya sistem pengendalian internal ayng bagus saat itulah top management dapat mengharapkan kebijakan untuk dipatuhi, asset perusahaan dilindungi, serta penyelenggaraan pencatatan berjalan baik

Dalam suatu perusahaan, pengendalian internal sangat penting guna mengawasi asset perusahaan. Pengendalian internal perusahaan dapat mencapai tujuan, maka perusahaan harus mempertimbangkan elemen sistem pengendalian internal. Toko Bapak Waluyo telah melakukan sistem pengendalian internal yang sesuai dengan elemen.

a. Lingkungan Pengendalian

Penggambaran keseluruhan sikap manajemen, direksi serta pemilik dari suatu entitas dalam lingkungan pengendalian terdiri dari sebuah Tindakan dan juga kebijakan, menurut Hartadi (2010). 
Dalam kegiatan pengendalian persediaan di Toko Bapak Waluyo terdiri kebijakan dan prosedur yang telah diciptakan oleh pemilik toko guna memberikan kemungkinan yang memungkinkan bahwa system pengendalian persediaan barang dagangan yang diterapkan telah dilakukan dalam beberapa kategori :

1. Pemisahan tugas yang cukup

Dalam kegiatan penjualan, order, pembelian dan penerimaan barang seluruh kegiatan berjalan sesuai perosedur, sehingga dapat teratasi dengan baik.

2. Otorisasi atas transaksi dan aktivitas:

Setiap keputusan tentang kegiatan toko, harus melakukan koordniasi dengan pemilik toko, dan keputusan akhir, pemilik toko harus menyetujui. Dalam persediaan barang Toko Bapak Waluyo, bagian administrasi melaporkan barang yang kurang, sehingga pemilik toko dapat memutuskan untuk order barang apa saja.

b. Penilaian Resiko

Penilaian resiko ialah pengidentifikasian atas factor yang mempengaruhi resiko, nilai pentingnya resiko serta kemumgkinan terjadi, dan penentuan Tindakan yang perlu dilakukan guna menangani resiko (Hartadi, 2010). Penilaian resiko guna meminimalisir adanya kerugian yang dilakukan di Toko Bapak Waluyo baik dilihat dari pencatatan sistem persediaan menggunakan system FIFO (First in First Out), dimana barang yang keluar pertama ialah barang yang masuk pertama. Meskipun, Toko Bapak Waluyo merupakan toko barang yang tidak memiliki resiko kadaluarsa akan tetapi penggunaan Sistem FIFO mampu meminimalisir resiko kerusakan barang yang terjadi karena adanya penyusutan barang atau keadaan gudang yang tertutup dan lembab. Stock Opname dilakukan setiap akhir bulan dengan tujuan untuk memastikan keadaan fisik stock dengan pencatatan persediaan barang yang telah dibuat, hal ini untuk meminimalisir resiko terjadinya penyelewengan karyawan terhadap barang-barang persediaan toko.

c. Aktivitas Pengendalian

Aktivitas pengendalian ialah strategi serta prosedur, selanjutnya yang sudah dimaksudkan dalam keempat elemen lainnya dapat membantu guna meyakinkan bahwa tindakan yang terkemuka telah dilakukan guna melampaui resiko dalam pencapaian tujuan organisasi.

Dalam praktek kegiatan pengendalian di Toko Bapak Waluyo dilakukan sesuai tugas serta tanggung jawab masing-masing bagian dalam pengawasan langsung pemilk toko, hal ini guna menunjang kegiatan pengendalian yang baik di Toko Bapak Waluyo.

d. Informasi dan Komunikasi 
Pengawalan pencatatan, pemrosesan serta pelaporan transaksi-transaksi yang terjadi dalam suatu entitas guna penjagaan akutabilitas harta yang terkait merupakan tujuan dari adanya sistem infromasi dan komunasikasi akuntansi pada suatu entitas.

Toko Bapak Waluyo mengetahui pengendalian dalam Informasi dan komunikasi berjalan baik dimana setiap bagian bertanggung jawab atas pelaporan sesuai dengan bagian masing-masing. Setiap bagian memiliki tanggung jawab dan dilaporkan dalam bentuk laporan. Baik kasir, administrasi bahkan pramuniaga memiliki kewajiban untuk melaporkan kegiatan yang dilakukan.

e. Pengawasan

Kegiatan pengawasan yang berkaitan dengan penilaian berkala atas kualitas pengendalian internal oleh manajemen guna menemukan suatu pengendalian internal yang diberlakukan sesuai tujuan serta telah dimodifikasi apabila diperlukan perubahaan keadaan. Penjagaan Toko Bapak Waluyo cukup baik diaman struktur organisasi yang sederhana, sehingga job description berjalan secara relevan, serta adanya pengawasan secara langsung dari pemilik. Sehingga memiliki otoritas penuh dalam setiap informasi yang dilaporkan ke pemilik toko, serta segala Tindakan yang diambil sesuai dengan keputusan pemilik toko.

\section{KESIMPULAN DAN SARAN}

\section{A. Kesimpulan}

1. Toko Bapak Waluyo sudah memiliki struktur organisasi yang memuaskan sehingga telah sesuai kebutuhan. Selain itu, struktur organisasinya didukung beberapa tugas, fungsi dan tanggung jawab disetiap bagian dalam pelaksanaan tugas serta tanggung jawab masingmasing.

2. Sistem informasi akuntansi persediaan barang di Toko Bapak Waluyo dalam penerapannya telah memuaskan serta didukung adanya sistem pencatatan yang baik. Sistem informasi persediaan barang yang dipakai ialah manual. Namun, tidak menurunkan keefektivan sistem informasi yang diterapkan serta masih tetap terkontrol dengan baik

3. Dalam Toko Bapak Waluyo, sistem pengendalian internal yang diterpakan telah sesuai dengan elemen pengendalian, yang dimana sudah terdapat pembagian tugas yang jelas guna membantu pengendalian internal Toko Bapak Waluyo. Selain tu, setiap bagian sudah memiliki coordinator yang bisa membantu pemilik toko dalam pengecekan setiap kegiatan toko supaya tidak terjadi penyelewangan. 


\section{B. Saran}

1. Akan lebih baik apabila sistem informasi akuntansi di bagian persediaan menggunakan sistem informasi secara digital sesuai dengan sistem informasi akuntansi yang dibutuhkan, hal ini supaya lebih mudah dalam proses pencatatan. Akan tetapi, sistem informasi secara manual dihilangkan, melainkan sistem informasi secara manual tetap digunakan sebagai dokumen pendamping. Sehingga dapat mempermudah bagian akuntansi dalam mengatasi adanua kesalahan dalam pencatatan ataupun hal lain yang mendukung kegiatan Toko Bapak Waluyo.

2. Toko Bapak Waluyo dalam pelaksanaan pengendalian internal sebaiknya terus ditingkatkan guna penjagaan dalam penerimaan serta pencatatan persediaan yang sesuai dengan prosedur dan mampu meminimalisir adanya kerugian dalam perusahaan. 


\section{DAFTAR PUSTAKA}

Baramuli, Friska, 2015, "Analisis Sistem Informasi Akuntansi Persediaan pada Yamaha Bima Motor Toli-Toli”. Jurnal EMBA 2303-1174 Vol. 3. No. 1.2302-1175,Fakultas Ekonomi dan Bisnis Universitas Sam Ratulangi. Manado.

Baridwan, Zaki, 2013. Sistem Informasi Akuntansi. Edisi Kedua. Salemba Empat. Jakarta.

Diana Anastasia, Setiawati Lilis. 2011. Sistem Informasi Akuntansi. Edisi Kesatu. Penerbit Andi. Yogyakarta.

Hartadi, Bambang, 2010. Sistem Pengendalian Intern dalam Hubungannya dengan Manajemen dan Audit. Penerbit Fakultas Ekonomu. Yogyakarta.

Ikatan Akuntan Indonesia. 2015. Akuntansi Dasar (Sesuai dengan PSAK terkini). Penerbit Ikatan Akuntan Indonesia.

Krismiaji. 2010. Sistem Informasi Akuntansi. Edisi Keempat. UPP AMP YPKN. Yogyakarta.

Manopo, Gracias, 2016, “Evaluasi Penerapan Sistem Informasi Akuntansi Atas Siklus Pendapatan pada PT. PLN (PERSERO) Manado" Journal EMBA Vol.4 No.1, 743- 859.

Mulyadi. 2015. Sistem Akuntansi. Edisi Keempat. Salemba Empat. Jakarta.

Prabowo, R. G. M., Hariyanti, T. P., \& Marlena. (2021). ANALISIS PENGENDALIAN INTERNAL JIMEA / Jurnal Ilmiah MEA ( Manajemen , Ekonomi , dan Akuntansi ). 5(3), 2485-2496.

Soemarso, S.R. 2009. Akuntansi Suatu Pengantar. Edisi Lima. Salemba Empat. Jakarta.

Sugiyono. 2010. “Metode Penelitian Bisnis”. Penerbit Alfabet, Bandung.

Sujarweni, V. Wiratna. (2020). Sistem Akuntansi. Yogyakarta : Pustaka Baru Press. 